\title{
USING SOCIAL NETWORKS IN EDUCATION
}

\author{
Engin Evni \\ Mr., National University of Uzbekistan, Uzbekistan, enginevni@gmail.com
}

\begin{abstract}
Change and development are bound to occur in every field of social life. The centres of the change to occur in the area of education are the schools. Increasing student success is related to the continuous and creative operation of the schools in this process. Schools should put this change and the transformation surrounding themselves into practice within the body of their own organizations. Technological developments need to be integrated into school programs and the teachers should be informed in this regard. The teacher must be a part of this change. Teachers must adapt to both their professional development and the changes in the education and training environments. Increasing use of social media every other day will help this change.

Education is an indispensable element of social life. The most important investment a society may make in their own future is education which includes the transfer of culture. As education is so much important, the significant role of the teachers comes to the fore one more time. In order to raise individuals beneficial to their societies, it is a must to shape the education and training environment in line with the requirements of a transformed world. In a world where society shapes the educational environment and the educational environment shapes the school, it is required to restructure the education and training environment in a way that fits with the future needs and to design it in a manner that meets the current necessities of the renewed world.

In today's world, developing technologies lead to the emergence of new approaches in the area of education. Traditional learning equipment gives room to educational technologies in time. In this respect, social networks provide a conducive environment for learning and education. Teachers have the opportunity to increase their knowledge, skills, and capabilities by using social networks.

This research studied how and to what extent social networks are used in the area of education and training. A mixed-method (ordered alternatives design) was used in the research to collect and analyze the quantitative and qualitative data sequentially. The data of the research were obtained from the branch teachers serving at the secondary schools in the province of Nevşehir that are affiliated with the Republic of Turkey Ministry of National Education.

It is found during the research that teachers are actively using social networks and that they tend to access and analyze the information and contents shared in the social network groups, and to contribute to such contents. Moreover, the teachers mentioned that they personally make use of various social network contents in the education and training environment.
\end{abstract}

Keywords: Social networks, social media, use of technology in the education-training environment, use of technology in education.

\section{INTRODUCTION}

Change and development are bound to occur in every field of social life. The centers of the change to occur in the area of education are the schools. Increasing student success is related to the continuous and creative 
operation of the schools in this process. Schools should put this change and the transformation surrounding themselves into practice within the body of their own organizations. Technological developments need to be integrated into school programs and the teachers should be informed in this regard. The teacher must be a part of this change. Teachers must adapt to both their professional development and the changes in the education and training environments. Increasing use of social media every other day will help this change.

Education is an indispensable element of social life. The most important investment a society may make in their own future is education which includes the transfer of culture. As education is so much important, the significant role of the teachers comes to the fore one more time. In order to raise individuals beneficial to their societies, it is a must to shape the education and training environment in line with the requirements of a transformed world. In a world where society shapes the educational environment and the educational environment shapes the school, it is required to restructure the education and training environment in a way that fits with the future needs and to design it in a manner that meets the current necessities of the renewed world.

The development of communication tools and internet technologies has swiftly changed individuals' lifestyles and habits. In parallel with technological development, various communication tools have also emerged. Especially the internet, which is the most widely used communication technology, is observed to be used in each and every sector. The primary facility offered by the internet is the establishment of fastpaced communication in social groups thanks to social networks. Nowadays people use social networks in taking note of, and to discuss, their daily lives and to come up with new (Beril, A. \& Mikail, B., 2010). Thanks to the opportunities provided by social networks, the number of users of this technology has gradually increased as well. Social networks have now become an integral part of our daily lives. Many social network websites have emerged and these websites reshaped the communication, interaction, cooperation, work, and even education processes of the people(Crocker, L. \& Algina, J.,1986). At this point, a question comes to mind whether social networks are used sufficiently for educational purposes in school life. The time spent by users in social networks has increased two or three times since the first social networks started to emerge. The users take place in social networks with their real identities and can share any information freely. As social network websites have become this much widespread, it is now essential to use them effectively in educational processes for various purposes.

It is observed that thanks to the internet, particularly adolescents and young adults use social networks to generate and share information. The use of social networks in education and training environments is envisaged to ensure more efficient communication among the students and teachers. Teachers and students must adapt to use social networks not only for diversification of educational tools and development of educational activities but also to make use of the opportunities offered by social networks in the best way [9]. Teachers may be able to get in touch with their students, learn about their problems or provide course materials through these social networks. This strengthens their communication with their students. As social networks are easily accessible by everyone, it is indispensable for the teachers to use them in their own professional development and also the education and training environment (Özmen, F., Aküzüm, C., Sünkür, M., \& Baysal, N. 2011). His template will assist you in formatting your paper. Please, copy it on your computer and insert the text keeping the format and styles indicated. The various components of your paper (title, abstract, keywords, sections, text, etc.) are already defined on the style sheet, as illustrated by the portions given in this document.

\section{ANALYSIS AND RESULTS}

\subsection{Research Methodology}

This research applied a mixed-method whereby quantitative and qualitative methods are used collectively. The quantitative part of the research is constituted by 258 teachers serving at 89 secondary schools. On the other hand, the working group of the qualitative part of the research consists of 20 branch teachers.

Mixed method researches are defined as the combination of qualitative and qualitative methods, approaches, and concepts within a study or subsequent studies. Doing mixed method research is the presentation, analysis, and combination of cases by using various methods within a single framework (Johnson, R. B., \& Onwuegbuzie, A. J. (2004). The basic proposition of mixed-method is mentioned to be the fact that using quantitative and qualitative approaches together ensures a better understanding of research problems than using the two approaches separately (Creswell, J. W. 2003)].

\subsection{Analysis}

In the quantitative part of the research, interviews were made with 258 teachers and in its qualitative part 
with 20 teachers. Table 1 presents the gender, seniority, and branch information of the teachers who participated in the research. Frequency and percentage values are used in the analysis of teachers' personal data.

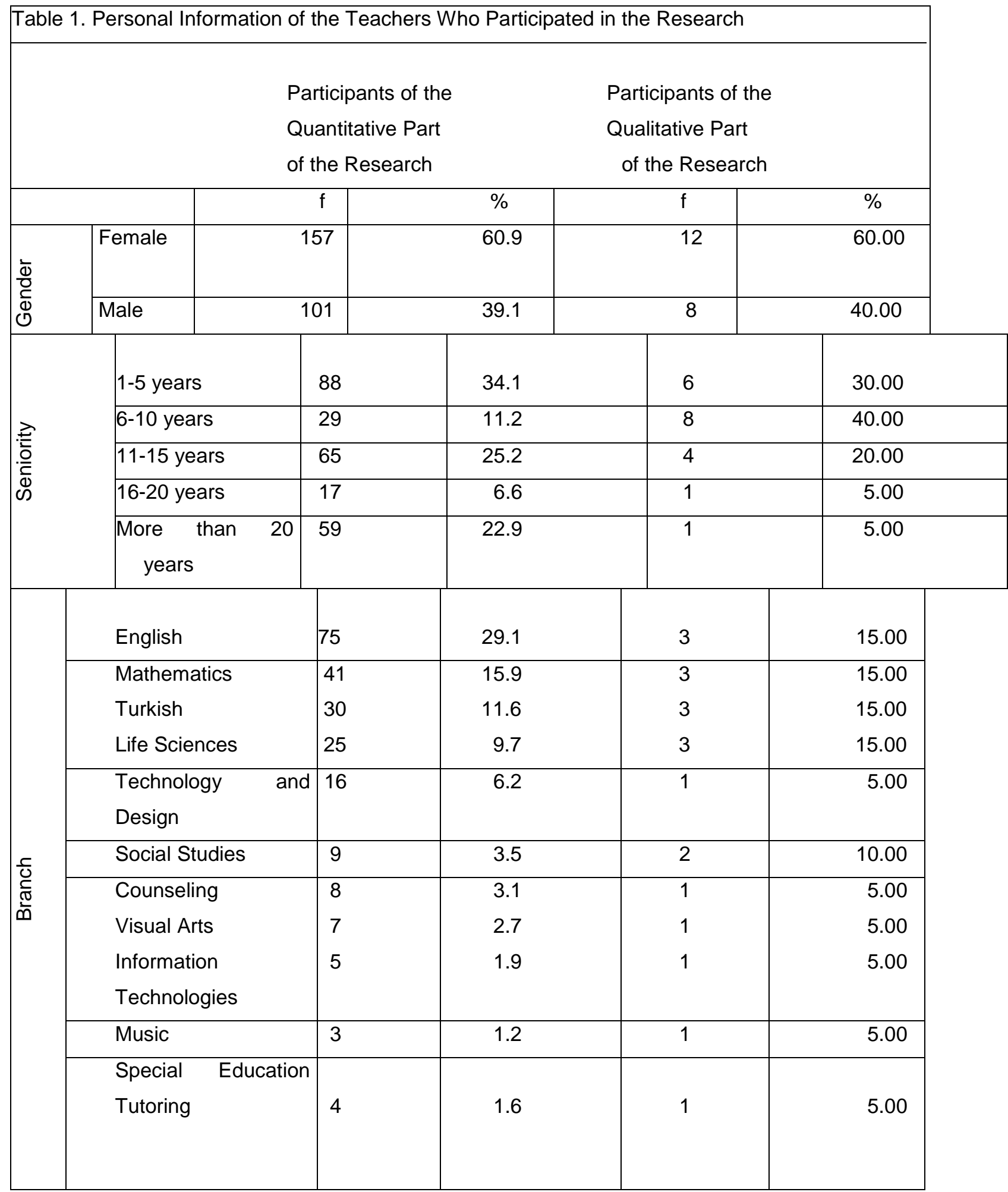

A method to understand the reliability of quantitative data is the Cronbach Alpha coefficient method. If the alpha coefficient is between 0.7 and 1.00, this means that the questionnaire is reliable [4]. For our 20-item scale used in the research, Cronbach's Alpha Reliability value is found as 0.817 . The findings regarding the scale's Cronbach's Alpha reliability value are presented in Table 2. 
Table 2. Reliability Analysis

\begin{tabular}{|c|c|}
\hline Cronbach's Alpha Value & Number of Items \\
\hline 0.817 & 20 \\
\hline
\end{tabular}

Social Network Types Widely Used by Teachers

The findings regarding the social network types widely used by teachers are presented in Table 3 .

Table 3. Social Network Types Widely Used by Teachers

\begin{tabular}{|l|c|c|}
\hline & $f$ & $\%$ \\
\hline Whatsapp & 241 & 93.3 \\
\hline Facebook & 210 & 81.1 \\
\hline Instagram & 155 & 60.2 \\
\hline YouTube & 86 & 33.5 \\
\hline Twitter & 70 & 27.2 \\
\hline Google+ & 53 & 20.5 \\
\hline Flickr & 7 & 2.8 \\
\hline MySpace & 4 & 1.6 \\
\hline
\end{tabular}

When Table 3 is analyzed, it is understood that teachers have more than one social network account. It is seen that an overwhelming majority of the teachers who participated in the research use Whatsapp social network applications. Other social networks that are widely used by teachers are Facebook, Instagram, Youtube, Twitter, Google+, Flickr, and Myspace.

\section{Usage Frequency of Social Networks by Teachers}

The findings regarding the usage frequency of social networks by teachers are presented in Table 4 .

\begin{tabular}{|c|c|c|c|l|l|}
\hline \multicolumn{2}{|c|}{ Table 4. Usage Frequency of Social Networks by Teachers } \\
\hline \multirow{2}{*}{} & A few times a week & 18 & 7.0 & & \\
\hline & $1-5$ times daily & 86 & 33.3 & & \\
\cline { 2 - 6 } & $6-10$ times daily & 65 & 25.2 & & \\
\cline { 2 - 6 } & $10-20$ times daily & 53 & 20.5 & & \\
\cline { 2 - 6 } & & & & & \\
\hline
\end{tabular}




\begin{tabular}{|c|c|c|c|l|l|}
\hline & $\begin{array}{c}\text { More than } 20 \text { times } \\
\text { daily }\end{array}$ & 36 & 14.0 & & \\
\cline { 2 - 5 } & Total & 258 & 100.0 & & \\
\hline
\end{tabular}

When Table 4 is analyzed, it is understood that one in every three teachers checks their social network 1 to 5 times daily. The rate of those who check their social network 6 to 10 times daily is $25 \%$, those who check 10 to 20 times is $20 \%$, those who check more than 20 times is $14 \%$, and those who check their social networks a few times weekly is $7 \%$. These results indicate that more than half $(58 \%)$ of the teachers check their social media accounts 1 to 10 times daily. These results show that teachers use social networks actively in their daily lives.

Crosstab of Usage Frequency of Social Networks by Teachers according to their Professional Seniority

The crosstab indicating the usage frequency of social networks by teachers according to their professional seniority levels is presented in Table 4.3.

\begin{tabular}{|c|c|c|c|c|c|c|}
\hline & & $\begin{array}{l}\text { How man } \\
\text { network a }\end{array}$ & $\begin{array}{l}\text { times on } \\
\text { unt daily? }\end{array}$ & verage do & you check & jour social \\
\hline & & $\begin{array}{l}\text { A few } \\
\text { times a } \\
\text { week }\end{array}$ & $\begin{array}{l}1-5 \text { times } \\
\text { daily }\end{array}$ & $\begin{array}{l}6-10 \text { times } \\
\text { daily }\end{array}$ & $\begin{array}{c}10-20 \\
\text { times daily }\end{array}$ & $\begin{array}{l}\text { More than } \\
20 \text { times } \\
\text { daily }\end{array}$ \\
\hline Professional & $1-5$ years & 0 & $31 \%$ & $19 \%$ & $32 \%$ & $18 \%$ \\
\hline & $6-10$ years & $10 \%$ & $39 \%$ & $27 \%$ & $10 \%$ & $13 \%$ \\
\hline & $\begin{array}{l}11-15 \\
\text { years }\end{array}$ & $6 \%$ & $40 \%$ & $17 \%$ & $18 \%$ & $18 \%$ \\
\hline & $\begin{array}{l}16-20 \\
\text { years }\end{array}$ & $32 \%$ & $55 \%$ & 0 & $13 \%$ & 0 \\
\hline & $\begin{array}{l}\text { More than } \\
20 \text { years }\end{array}$ & $33 \%$ & $28 \%$ & $17 \%$ & $15 \%$ & $8 \%$ \\
\hline & & & & & & \\
\hline
\end{tabular}

When Table 5, namely the crosstab indicating the usage frequency of social networks by teachers according to their professional seniority levels, is analyzed, it is seen that those teachers with high seniority levels use social networks less than others. For instance, when the usage frequency of the teacher group with more than 20 years of professional seniority is analyzed, it was observed that the percentage of checking their social networks a few times a week is $33 \%$, percentage of checking 1 to 5 times daily is $28 \%$, percentage of checking 6 to 10 times daily is $17 \%$, percentage of checking 10 to 20 times daily is $15 \%$ and percentage of checking more than 20 times daily is $8 \%$. And it is understood that for the teacher group with professional seniority of 1 to 5 years, the frequency of checking their social networks daily is more than the others.

These results have similarities with Akçayır's (2014) research titled "Use of social networks by faculty 
members in educational environments". It is seen in Akçayır's (2014) research that those faculty members with more professional seniority use social networks less than the others. When all the results obtained are analyzed collectively, it is seen that there is a negative correlation between the years of service and the usage of social networks and that as the professional seniority of teachers increase, their use of social networks decreases.

Findings of the Contribution of the Use of Social Networks to Teachers' Professional Development according to the Gender Variable

Opinions of teachers on the contribution of the use of social networks to professional development were compared according to the gender variable through t-test and the results are provided in Table 4.4.

Table 6. T-Test Results on the Role of the Use of Social Networks in Teachers' Professional Development according to Gender Variable

\begin{tabular}{|l|c|c|c|c|c|c|c|}
\hline Dimension & Gender & $\mathrm{N}$ & $\overline{\mathrm{x}}$ & $\mathrm{SS}$ & $\mathrm{sd}$ & $\mathrm{t}$ & $\mathrm{P}$ \\
\hline $\begin{array}{l}\text { The Role of Social } \\
\begin{array}{l}\text { Networks on Teachers' } \\
\text { Professional } \\
\text { Development }\end{array}\end{array}$ & Female & 157 & 4.1293 & 0.48903 & 254 & 2.216 & 0.771 \\
\cline { 2 - 7 } & Male & 101 & 4.1059 & 0.58641 & & \\
\hline
\end{tabular}

When Table 6 is analyzed, it is understood that the opinions of teachers on the contribution of the use of social networks to professional development do not differ to a significant extent depending on gender [t(254) $=2.216, \mathrm{P}>0.05]$. The arithmetic means reflecting the opinions of teachers on this topic $(\overline{\mathrm{x}} \mathrm{k}=4.12: \overline{\mathrm{x}} \mathrm{e}=4.10)$ are seen to be close to each other in both of the genders.

Findings regarding the Use of Social Networks by Teachers in Education and Training Environment according to Gender Variable

The opinions of teachers on the use of social media in education and training environment are compared according to gender variable by using a t-test and the results are shown in Table 4.5.

Table 7. Results of T-Test Analysis on the Use of Social Networks in Educational Environment according to Gender Variable

\begin{tabular}{|l|c|c|c|c|c|c|c|}
\hline Dimension & Gender & $\mathrm{N}$ & $\overline{\mathrm{x}}$ & $\mathrm{SS}$ & $\mathrm{sd}$ & $\mathrm{t}$ & $\mathrm{p}$ \\
\hline $\begin{array}{l}\text { Use of Social } \\
\text { Networks in Education } \\
\text { and Training } \\
\text { Environment }\end{array}$ & Female & 157 & 3.9797 & 0.54945 & 254 & -2.337 & 0.016 \\
\cline { 2 - 7 } & Male & 101 & 4.2428 & 0.51473 & & & \\
\hline
\end{tabular}

When Table 7 is analyzed, it is understood that the opinions of teachers on the use of the social network in education and training environment do not differ to a significant extent based on gender $[\mathrm{t}(254)=-2.237, \mathrm{P}<$ 0.05]. When the arithmetic means reflecting teachers' opinions on this topic are analyzed, it is understood that male teachers $(\bar{x} e=4.24)$ use social networks in education and training environment more than female teachers $(\bar{x} \mathrm{k}=3.97)$. As a matter of fact, it is understood that male teachers $(X=4.37)$ agreed with the item "Social networks support education and training environment" that falls under this dimension at significantly higher levels than the female teachers $(X=3,98)$. The point averages of the scale items are presented in Annex 1. This result may be interpreted in the sense that male teachers use social networks to support education and training environments more than female teachers.

These results have similarities with those of Feyzioğlu's research (2016) titled "Views of school managers and teachers on the use of social media in education". In Feyzioğlu's research (2016), it was observed that the point average of male teachers' views on the use of social networks in education (84.74) is higher than female teachers' point averages (62.75) in that regard. When the results obtained are evaluated altogether, it may be stated that male teachers use social networks in the education and training environment more efficiently than female teachers. 
Findings regarding the Use of Social Networks by Teachers for Communication Purposes according to Gender Variable

The use of social networks by teachers for communication purposes was compared according to gender variable by using a t-test, and the results are shown in Table 4.6.

Comparison of the Teacher Opinions on the Use of Social Networks in Education and Training Environment with the Usage Frequency of Social Networks

One-way ANOVA analysis was made to compare the teacher opinions on the use of social networks in education and training environment with the usage frequency of social networks, and the results of this analysis are presented in Table 4.13.

Table 9. Results of One-Way Analysis of Variance according to Teacher Opinions on the Use of Social Networks in Education and Training Environment as well as the Usage Frequency of Social Networks

\begin{tabular}{|c|c|c|c|c|c|c|}
\hline Dimension & $\begin{array}{l}\text { Usage } \\
\text { Frequency }\end{array}$ & $N$ & $X$ & $F$ & $P$ & $\begin{array}{l}\text { Significant } \\
\text { Difference }\end{array}$ \\
\hline \multirow{5}{*}{$\begin{array}{l}\text { Education } \\
\text { Environment }\end{array}$} & $\begin{array}{c}\text { A few times a } \\
\text { week }\end{array}$ & 18 & 4.0000 & \multirow{5}{*}{1.809} & \multirow{5}{*}{0.128} & \multirow{5}{*}{ - } \\
\hline & $1-5$ times daily & 82 & 4.1293 & & & \\
\hline & $6-10$ times daily & 61 & 4.0918 & & & \\
\hline & $\begin{array}{l}\text { 10-20 times } \\
\text { daily }\end{array}$ & 53 & 4.0937 & & & \\
\hline & $\begin{array}{l}\text { More than } 20 \\
\text { times daily }\end{array}$ & 32 & 4.3000 & & & \\
\hline
\end{tabular}

One-way variance analysis was made in order to test whether there is a statistically significant difference between teachers' frequency of use of social networks and their use of them in education and training environments. When Table 4.13 is analyzed, it is understood that there is no statistically significant difference $[\mathrm{f}(251)=1.809, \mathrm{P}>\mathrm{.005}]$.

When the findings in Table 9 on the teachers' use of social networks in education and training environment in comparison with their social network usage frequency, are analyzed, it is seen that the highest arithmetic average is of the teacher group with more than 20 entries in social networks $(X=4.30)$. It is also observed that the teachers who enter social networks 1 to 5 times daily have an average value of $(X=4.12)$, the teachers who enter 10 to 20 times daily have $(X=4.09)$, the teachers who enter 6 to 10 times daily have $(X=4.09)$ and the teachers who enter a few times a week have $(X=4.00)$.

Comparison of Teacher Opinions on the Use of Social Network for Communication Purposes with Social Network Usage Frequency

One-Way Variance (ANOVA) analysis was made in order to compare teacher opinions on the use of the social network for communication purposes with social network usage frequency, and the results of this analysis are provided in Table 4.14.

Table 10. Results of One-Way Variance Analysis of Teacher Opinions on the Use of Social Networks for Communication Purposes according to Usage Frequency 


\begin{tabular}{|c|c|c|c|c|c|c|c|}
\hline Dimension & $\begin{array}{l}\text { Professional } \\
\text { Seniority }\end{array}$ & $\mathrm{N}$ & $\mathrm{X}$ & SS & $\mathrm{F}$ & $P$ & $\begin{array}{l}\text { Significant } \\
\text { Difference }\end{array}$ \\
\hline \multirow{5}{*}{ Communication } & $\begin{array}{l}\text { A few times } \\
\text { a week }\end{array}$ & 18 & 4.1667 & & \multirow{5}{*}{4,360} & \multirow{5}{*}{0,002} & \multirow{5}{*}{$\begin{array}{c}\text { A few times a } \\
\text { week } \\
\text { and } \\
\text { more than } 20 \\
\text { times }\end{array}$} \\
\hline & $\begin{array}{l}\text { 1-5 times } \\
\text { daily }\end{array}$ & 82 & 4.2854 & & & & \\
\hline & $\begin{array}{l}\text { 6-10 times } \\
\text { daily }\end{array}$ & 61 & 4.557 & & & & \\
\hline & $\begin{array}{l}\text { 10-20 times } \\
\text { daily }\end{array}$ & 53 & 4.2642 & & & & \\
\hline & $\begin{array}{c}\text { More than } 20 \\
\text { times daily }\end{array}$ & 32 & 4,6000 & & & & \\
\hline
\end{tabular}

One-way variance analysis was made in order to test whether there is a statistically significant difference between teachers' social network usage frequencies and their use of social networks for communication purposes. As it is presented in Table 10, it was found that there is a statistically significant difference between these two items $[f(251)=0.002, P<0.005]$. In order to test the source of this difference, the Tukey test, which is among post hoc tests, was used. Tukey test results are provided in Table 4.15.

Table 11. Results of Tukey Test Made for Teacher Opinions on the Use of Social Networks for Communication Purposes and the Frequency of Social Network Usage

\begin{tabular}{|l|l|l|l|l|}
\hline $\begin{array}{l}\text { How many times on average } \\
\text { do you check your social } \\
\text { network account in a day? }\end{array}$ & $\begin{array}{l}\text { How many times on average } \\
\text { do you check your social } \\
\text { network account in a day? }\end{array}$ & Mean Difference & Std. Error & Sig. \\
\hline \multirow{4}{*}{ A few times a week } & $1-5$ times daily & -.11870 & .12486 & .877 \\
\cline { 2 - 6 } & $6-10$ times daily & -.28907 & .12867 & .166 \\
\cline { 2 - 6 } & $10-20$ times daily & -.09748 & .13086 & .946 \\
\cline { 2 - 6 } & More than 20 times daily & $-.43333^{*}$ & .14133 & .020 \\
\hline \multirow{5}{*}{$1-5$ times daily } & A few times a week & .11870 & .12486 & .877 \\
\cline { 2 - 6 } & $6-10$ times daily & -.17037 & .08111 & .223 \\
\cline { 2 - 6 } & $10-20$ times daily & .02121 & .08454 & .999 \\
\cline { 2 - 6 } & More than 20 times daily & $-.31463^{*}$ & .09998 & .016 \\
\hline
\end{tabular}

When Table 11 is analyzed, it is understood that the direction of the difference is between the teachers with 20 daily entries and those with a few entries in a week and between the teachers with more than 20 daily entries and those with 1 to 5 daily entries. When these groups' arithmetic means are analyzed, it is seen that $X$ a few times a week $=4.16, X 1-5$ times daily $=4.28$, and $X$ more than 20 times daily $=4.60$. When the findings regarding teachers' use of social networks for communication purposes according to their social network 
usage frequencies, are analyzed, it is observed that those teachers who use social networks frequently, use them for communication purposes.

This section of the research is reserved for the findings obtained from the interviews made with teachers and for their interpretations. Participants consisted of a total of 20 teachers from various branches, 12 of them being female and 8 of them male. Being determined based on the principle of voluntariness, the participants verbally responded to the questions given in the semi-structured interview form which was prepared beforehand. Opinions of participants were recorded by an audio recorder upon the receipt of their consent and then the transcription of these records was transferred to a computer environment.

\section{Findings on the Use of Social Networks}

Participants were subjected to several questions about the use of social networks, such as "What do you think about teachers' use of social networks? How much time do you spend in social networks?" The themes and subthemes obtained from the responses of participants to these questions are shown in Table 11.

Table 12. Teachers' Use of Social Networks and Frequency of Use

\begin{tabular}{|c|c|c|c|}
\hline Theme & Subthemes & $f$ & $\%$ \\
\hline \multirow{5}{*}{$\begin{array}{l}\text { Negative sides } \\
\text { of social } \\
\text { networks }\end{array}$} & Taking too much time & 12 & 16.43 \\
\hline & $\begin{array}{l}\text { Entering social networks too many times means a waste of } \\
\text { time }\end{array}$ & 8 & 10.95 \\
\hline & Convenient for individual communication & 4 & 5.47 \\
\hline & Has too many distracting factors & 3 & 4.10 \\
\hline & Sharing posts in social networks regarding private life & 2 & 2.73 \\
\hline Total & & 29 & 39.72 \\
\hline \multirow{5}{*}{$\begin{array}{l}\text { Contributions } \\
\text { of social } \\
\text { networks }\end{array}$} & Enables fast-paced communication with school stakeholders & 13 & 17.80 \\
\hline & Enables to easily access most updated information & 11 & 15.06 \\
\hline & Enables teachers to follow professional novelties & 9 & 12.32 \\
\hline & It is possible to access networks anywhere and anytime & 7 & 9.58 \\
\hline & Being sensitive in the shared posts & 4 & 5.47 \\
\hline Total & & 44 & 60.27 \\
\hline Total & & 73 & 100 \\
\hline
\end{tabular}

Findings regarding the Use of Social Networks in Education and Training Environment

With regard to the use of social networks in education and training environments, participants are asked the question of "What do you think about the use of social networks in education and training environment and about its impact on education?" The themes and subthemes obtained from the responses given by the participants to the said question are provided in Table 13. 
Table 13. Use of Social Networks in Education and Training Environment

\begin{tabular}{|c|c|c|c|}
\hline Theme & Subthemes & f & $\%$ \\
\hline \multirow{9}{*}{$\begin{array}{l}\text { Supporting of } \\
\text { Learning and } \\
\text { Teaching } \\
\text { Environment }\end{array}$} & Attracts students' attention and accelerates learning & 5 & 10.63 \\
\hline & $\begin{array}{l}\text { Sharing materials that are rich in visual and audio content, such as } \\
\text { videos, during lessons }\end{array}$ & 5 & 10.63 \\
\hline & $\begin{array}{l}\text { Enabling fast-paced communication with the students outside the } \\
\text { school and responding to their questions }\end{array}$ & 4 & 10.63 \\
\hline & Making activities swiftly in the lessons & 4 & 8.51 \\
\hline & $\begin{array}{l}\text { Similar to Fatih Project and the use of EBA, and supported by the } \\
\text { Ministry of National Education }\end{array}$ & 4 & 8.51 \\
\hline & Saves time and gives room for more activities & 4 & 8.51 \\
\hline & Passing on national and moral values fast & 4 & 8.51 \\
\hline & Enhances student motivation within the school & 3 & 6.38 \\
\hline & $\begin{array}{l}\text { Widespread nature of e-learning, web-based and online learning in } \\
\text { today's world }\end{array}$ & 3 & 6.38 \\
\hline Total & & 39 & 82.97 \\
\hline \multirow{4}{*}{$\begin{array}{l}\text { Being a } \\
\text { Distraction }\end{array}$} & $\begin{array}{l}\text { Not of the opinion that social networks will be effective in an } \\
\text { educational environment }\end{array}$ & 3 & 6.38 \\
\hline & Usability of social networks under certain limitations & 2 & 4.25 \\
\hline & $\begin{array}{l}\text { Management of social networks may depend on the technological } \\
\text { literacy of the teacher }\end{array}$ & 2 & 4.25 \\
\hline & A venue undergirding bad behavior & 1 & 2.12 \\
\hline Total & & 8 & 17.02 \\
\hline Total & & 47 & 100 \\
\hline
\end{tabular}

When teachers' opinions on the use of social networks in education and training environment are analyzed, it is seen that these opinions may be evaluated under 13 different subthemes. When the subthemes obtained from participant opinions are assessed altogether, two main themes emerge. These themes may be called social networks' support for education and training environment, and the problems of distraction and lack of focus that may be faced by students due to the use of the social network in education and training environment. Moreover, most of the teachers talked about the benefits of using social networks in the field of education. They mentioned that social networks may help students to learn fast and that lessons have become richer in audio-visual terms by the use of social networks.

\section{RESULT}

1. It was observed that an overwhelming majority of teachers actively use social networks and have more than one social network account. The social networks most frequently used by teachers are Whatsapp, Facebook, and Instagram.

2. When teachers' usage frequencies are analyzed, it is seen that approximately one-third of them check or use their social networks 1 to 5 times daily, approximately one-fourth of them 5 to 10 times daily, 
approximately one-fourth of them 10 to 20 times daily. When teachers' frequency of use of social networks is analyzed, it is seen that teachers check their social networks approximately 6 to 10 times daily.

3. Teachers mentioned that they use social networks in education and training environments. It was observed that male teachers use social networks in education and training environments more than female teachers. Teachers stated that social networks enrich the education and training environment in terms of visual and audio content and ensure permanent learning.

4. It was observed that social networks are used as a fast-paced communication tool among teachers, students, school managers, and parents/guardians. Female teachers mentioned that they use social networks for communication purposes, more than male teachers.

5. It was observed that those teachers who use and check their social networks more frequently, use them mostly for communication purposes. Those teachers who check and use their social networks more than 20 times daily, mentioned that they use social networks for communication purposes more than those teachers who check or use their social networks a few times a week.

6. Teachers communicated their purposes in signing up to social networks as following contents, investigation, access to new professional information, and contribution to comments within groups. They stated in this regard that they follow contents about their professional development process and interact with other people in social networks. Moreover, teachers mentioned that through social networks, they share documents, as well as information and data about their profession and professional benefits and central examinations such as the ones for promotion.

\section{CONCLUSION AND RECOMMENDATION}

1. Teachers complain about the fact that only certain people produce content in social networks, and about the limited nature of content diversification and repeating contents. In this respect, virtual studios and content management training programs should be organized so as to ensure teachers' online content generation and thus to help more and more teachers or teacher groups to produce content.

2. A nationwide educational social network website must be established within the body of the Ministry of National Education and it must be ensured that school employees carry out their educational activities through this social network website.

3. A formal account may be established for the school in social networks so as to generate a platform enabling communication among educational managers, teachers, parents/guardians, and students, and the benefits of such an endeavor may be analyzed.

4. Research may be conducted on the use of social networks covering primary school and preschool teachers.

5. Interaction of teachers located in demographically different geographies may be analyzed by ensuring the use of social networks by teachers working in different educational regions.

6. By inclusion of the whole of an educational region in an educational social network, interactions among teachers, the posts shared among the teachers within the same community, and the resulting impact on their professional development may be analyzed.

7. Communication in social network groups established by teachers may be analyzed.

\section{REFERENCE LIST}

Akçayır, G. (2014). Öğretim Üyelerinin Eğitim Ortamlarında Sosyal Ağları Kullanma Durumları (Use of Social Networks by Faculty Members in Educational Environments). Unpublished Master's Thesis. Ankara: Gazi University.

Beril, A. \& Mikail, B. (2010). Yeni Bir İletişim Ortamı Olarak Sosyal medya: Ege Üniversitesi İletişim Fakültesine Yönelik Bir Araştırma (Social Media as a New Communication Medium: A Research Made on Ege University's Faculty of Communication), Journal of Yaşar University, 20(5), 33483382.

Creswell, J. W. (2003). Research design: Qualitative, quantitative, and mixed methods approaches (2nd 
ed.). Thousand Oaks, CA: Sage.

Crocker, L. \& Algina, J. (1986). Introduction to Classical and Modern Test Theory. Fort

Worth: Holt, Rinehart and Winston.

Gülbahar, Y., Kalelioğlu, \& F., Madran, O., (2010), Sosyal ağların Eğitim Amaçlı Kullanımı (Use of Social Networks for Educational Purposes), Başkent University, Department of Computer Education and Instructional Technologies, Ankara.

Johnson, R. B., \& Onwuegbuzie, A. J. (2004). "Mixed methods research: A research paradigm whose time has come". Educational Researcher, 33(7): 14-26.

Murat, E. \& Mübin, K. (2012). Sosyal ağların Eğitim Bağlamında Kullanımı (Use of Social Networks in the Context of Education). Sosyal Bilimler Dergisi(Journal of Social Sciences), Uşak University 5/2, 156167

Özmen, F., Aküzüm, C., Sünkür, M., \& Baysal, N. (2011). Sosyal ağ Sitelerinin Eğitsel Ortamlardaki İşlevselliği(Functionality of Social Network Websites in Educational Environments),6th International Advanced Technologies Symposium (IATS'11), 16-18 May 2011, Elazığ, Turkey, Fırat University, 42-47.

Tiryakioğlu, F. and Erzurum, F. (2011). Bir Eğitim Aracı Olarak Ağların Kullanımı (Use of Networks as an Educational Tool), 2nd International Conference on New Trends in Education and Their Implications 27-29 April, 2011 Antalya-Turkey, 1031-1047. 